\title{
Verbal and multimodal metaphorical patterns in Wikipedia migration discourse
}

\author{
Janja Polajnar
}

DOI: 10.18355/XL.2021.14.02.14

\begin{abstract}
The use of metaphors in the refugee discourse since 2015 has so far mostly been explored in newspapers in different EU countries. In this study, we combine linguistic discourse metaphor analysis with a corpus-based approach, complementing qualitative and quantitative corpus evidence from Wikipedia migration corpus to explore verbal and multimodal metaphorical patterns. As a multimodal and multilingual hypertext, Wikipedia, represents a highly relevant source of information and a unique source for the multimodal and cross-linguistic discourse linguistic analysis. In this paper metaphorical expressions are considered as a transtextual discursive phenomenon in the light of Foucaudian tradition. The results of the study show that the analyzed migration discourse in Wikipedia is like the newspaper migration discourse predominantly structured by metaphorical patterns that draw from the source domains water flow/natural catastrophes as well as military/warfare. These source domains are conventionally used in relation to a wide range of target domains (multivalency), however, they play a constitutive role in the analyzed discourse by providing a specific view of events and emphasizing certain aspects and evaluations. The patterning of water flow metaphors across Wikipedia articles and talk pages is in multimodal metaphors extended, elaborated and reinforced in visual mode, referring to those migrating as a flow, wave, influx. However, especially on Wikipedia talk pages Wikipedians point to the dehumanization of those fleeing and the securitization of migration through metaphorical expressions as a problematic linguistic discourse practice.
\end{abstract}

Key words: verbal and multimodal metaphors, linguistic discourse analysis, migration discourse in German Wikipedia

\section{Introduction}

In the 20th century, the use of metaphors is considered ubiquitous not only in fictional and rhetorical texts, but also in everyday language, scientific texts, in political and public mass media disourse and beyond (Lakoff, Johnson, 1980), (Semino, 2008), (Brandt, 2004), (Kovacs, 2009) etc. In the 1990s, metaphor analysis was established as an approach to analyze topic-specific discourse (e.g. migration discourse), understanding metaphors as transtextual patterns and as such discursive phenomena (Semino, 2008), (Gredel, 2015). In a topic-specific discourse, metaphorical patterns are not only used to describe complex experiences and phenomena in a vivid and consice way (illustrative funcition), but "can lead to the construction of new meanings by bringing together different ideas and systems of knowledge" (Deignan, 2005: 9). As discourse patterns metaphors constitute and structure topic-specific discourses, evaluating groups of people, events, experiences and focusing only particular aspects of the described phenomena (perspectivation) (Liebert, 2001), (Gredel, 2015), (Spieß, 2014, 2017a), (Polajnar, Gredel 2018). A such they represent powerful linguistic means, used to refute arguments of discourse participants (argumentative function) and as means of persuasion (Spieß/Köpcke, 2014: 3-10). Besides indicating opinion, metaphors can also "dominate the tone" in topic-specific discourse (Gredel, 2015: 43). In migration-related discourse, many studies focusing on different time periods and countries suggest, that European migration processes are commonly constructed

XLinguae, Volume 14 Issue 2, April 2021, ISSN 1337-8384, eISSN 2453-711X 
through the source domain of water flow and natural catastrophes, comparing those migrating with a flow, an influx, or a wave (Turton, 2003). ${ }^{1}$ Furthermore, the same can be summed up from the recent studies on the refugee crisis since 2015 as analyzed, for example, in German newspapers (Spieß, 2017b), in talks of German right-wing populist politicians (Gür-Șeker, 2019a), in the Italian media (IsselDombert, Wieders-Lohéac, 2018), in a Croatian newspaper (Šaina, 2016) or in the Slovenian national public broadcasting service MMC RTV Slovenia (Fijavž, Fišer, 2020 ) etc. The latter critical discourse study points to the fact that the media coverage in 2015 was not only profoundly negative but further securitized migration by uncritically reproducing the (metaphorical) language of political discourse participants in reported statements. Fijavž and Fišer (2020: 80) speak of "naturalisation and sucessful resignification of migrations as a threat over the period". Though most studies provide systematic evidence that discursive metaphors of water flow are used in a negative way in migration discourse, Salahshour (2016) shows that they can refer to those migrating in a positive way, i.e. as having a positive effect on New Zealand's economy. Migration discourse has, moreover, been constructed by metaphors from further source domains, e.g. warfare/military, vehicles/machines, products (Nier, 2020), (Böke, Jung, Niehr, Wengeler, 2000), (Gür-Şeker, 2019a) and death (Issel-Dombert, Wieders-Lohéac, 2018). In these studies, a precise analytical focus on verbal metaphors in newspapers can be observed (criticised as ,newspaper bias" by Warnke, 2012: 191). By analyzing multimodal metaphors in the free encyclopaedia Wikipedia we expand the scope as to related studies twofold: genre (encyclopaedic texts and related discussions) and mode of metaphors. This paper analyzes how metaphorical patterns are manifested verbally and multimodally through verbal and visual modes with a focus on how these metaphors construct metaphorical scenarios of those migrating and migration since 2015 in Wikipedia articles and talk pages.

\section{Theoretical framework}

\subsection{Linguistic discourse analysis}

Linguistic discourse analysis ${ }^{2}$ in the tradition of Foucault refers to transtextual linguistic analysis, focusing on recurring patterning across various text, even whole "text formations" which deal with a particular topic (Spitzmüller, Warnke, 2011: 9). In the 1980s Faulcauldian structuralist perspective of discourse was adopted to linguistics by Dietrich Busse (1987) and enhanced with the aspect of the agency. The term "discourse" was defined as an intertextually intertwined network of texts and utterances on a particular topic (Busse, Teubert, 1994) and later expanded to also include non-verbal elements (Klug, 2018), e.g. migration discourse since 2015 as analyzed in this paper. Busse and Teubert (1994) further argued that discourse as a linguistic object can only be analyzed if defined as a virtual corpus of topic-specific texts. This represents a starting point for the approaches combining linguistic discourse analysis with corpus linguistics (Stefanowitsch, 2006), (Bubenhofer, 2009), (Gür-Șeker, 2012). In comparison to critical discourse analysis, analyzing how predominant social groups affect both public discourse and other social groups (van Dijk, 1993), linguistic discourse analysis focuses on linguistic patterns in relation to (institutional) discourse participants and how these patterns structure topic-specific discourses. However, linguistic discourse analysis can also critically comment on the use of the unveiled linguistic patterns, such as the use of metaphorical patterns of water flow and warfare in the recent migration discourse as analyzed in this paper.

\footnotetext{
${ }^{1}$ Metaphorical patters from the source domain water flow/natural catastrophes were predominant in migration discourse after World War II in Germany (Böke, 1997), in 1996/1997 migration in France (van der Valk, 2003) or in 2003 migration in Great Britain (Baker, McEnery, 2005).

${ }^{2}$ It is to be noted that linguistic discourse analysis does not refer to conversational analysis.
} 
To analyze topic-specific discourse Spitzmüller and Warnke (2011: 22) propose the so-called "multilayer linguistic discourse analysis", where discourse represents the constituent of language above the text as well as above all the other layers, i.e. word-oriented layer analyzing idiosyncrasies, proposition-oriented layer with the analytical focus on metaphorical patterns etc. and text-oriented layer with focus on thematic developments, text types etc.

\subsection{Verbal and multimodal metaphorical discourse patterns}

Modern theories in the 20th century no longer categorize metaphors as mere stylistic ornaments, but as both linguistic and cognitive phenomena, fundamental for "our ordinary conceptual system, in terms of which we both think and act" (Lakoff, Johnson, 1980: 3). The core idea of "understanding and experiencing one kind of thing in terms of another" (ibid.: 5) is based on the interaction of two semantic fields ("target domain and source domain" (ibid.)), which can be traced back to Richards' "tenor and vehicle" (Richards, 1936: 95) and Black's "frame and focus" (Black, 1983: 58). However, in recent studies, scholars point to the complexity of metaphorical mappings and the limitation of this traditional source-target dichotomy. Musolff (2006) suggests that construed metaphors be considered a part of a metaphoric scenario in which metaphors show different levels of abstraction and stand in causeeffect relations. According to Conceptual Metaphor Theory (CMT), which differentiates between metaphorical expressions and conceptual metaphors, metaphors are "primarily a matter of thought and only derivatively a matter of language" (Lakoff, Johnson, 1980: 153). It is the patterning of metaphorical expressions in language that points to the existence of conceptual metaphors. Several scholars, however, critically comment on the lack of "explicit methodology for the extrapolation of conceptual metaphors from linguistic data" (Deignan, 2005: 10), (Semino, 2008), (Steen et al., 2010) as well as a lack of analytical focus on metaphorical expressions. Further criticism of CMT has been voiced in recent years on a theoretical and methodological level. Liebert (2001: 103) criticizes that CMT does not explain "temporal and ideational origins" of metaphors, i.e. when and why specific projections of cognitive models come into existence and why particular metaphors characterize the cultural coherence of present-day society. Therefore he argues that metaphors are not to be primarily conceived as cognitive phenomena with fixed metaphorical concepts but as sociocultural elements, dependent on sociocultural dynamics of language (Liebert, 2008). They are both context-dependent and fluid with respect to social and discourse contexts they are used in (ibid.). Similarly, Semino points out that "attention for the linguistic realizations of metaphorical patterns often leads to important observations on the effects of connotations and evaluative associations, which can easily be ignored in the current emphasis on the conceptual dimension of metaphor" (Semino, 2008: 136). Therefore Liebert (1996: 802) uses the term "proto-metaphor" instead of conceptual metaphor and defines proto-metaphors as highly frequent metaphors, typical for a particular thematic discourse, e.g. water flow metaphors or warfare metaphors for migration discourse as constructed in German language version of Wikipedia.

Since the 1990s, studies from linguistic discourse analysis have focused on metaphor patterning and thus on metaphors as transtextual patterns ${ }^{3}$ and as discursive phenomena, whose appearance, creative differentiation, variation, and disappearance depend on discourse dynamics (Gredel, 2014). As mentioned above, discursive

\footnotetext{
${ }^{3}$ Whereas metaphorical expression refers to one or more metaphorically used words of a particular source domain in in close proximity, metaphorical patterns refer the use of metaphorical expressions across different texts in a corpus (Semino, 2008: 112).
}

XLinguae, Volume 14 Issue 2, April 2021, ISSN 1337-8384, eISSN 2453-711X 
metaphors constitute and structure thematic discourses as well as display various functions (illustrative function, argumentative function, persuasive function etc.) (Pielenz, 1993), (Spieß/Köpcke, 2014). Though metaphors drawing from a certain source domain (e.g. source domain of water flow) frequently occur in different target domains (not only in relation to those migrating) (Spieß, 2017a), they provide a specific view of events and emphasize or focus on certain aspects in a particular topicspecific discourse.

Forceville (2006) argues that metaphors as cognitive phenomena can be manifested through different semiotic modes ${ }^{4}$ and thus examines metaphors in modes other than language alone. On the one hand, he extends the notion of verbal metaphor to non-verbal and on the other the notion of monomodal metaphor to a multimodal. He defines monomodal metaphors as "metaphors whose target and source are exclusively or predominantly rendered in one mode" (Forceville, 2006: 383) and multimodal metaphors as "metaphors whose target and source are each represented exclusively or predominantly in different modes" (Forceville, 2006: 384). Whereas "the similarity between target and source in monomodal metaphors is cued by the resemblance between them", in multimodal metaphors the similarity "is cued by coreferentiality /.../) or co-occurrence" (Forceville, 2016: 246). However, he acknowledges that a target and/or a source can often be "cued in more than one mode" and that it may differ from addressee to addressee "how necessary each of the modes is for identification of target and source" (Forceville, 2016: 255). For the purposes of this analysis, we define multimodal metaphors with respect to Forceville $(2006,2016)$ and Gredel (2014: 201) as follows: In multimodal metaphors, either a source or a target are encoded visually (or aurally). It is also possible that both domains of the multimodal metaphor are encoded verbally with the additional encoding of either a source or a target domain in the visual mode. Though theoretically different modes can be combined in a multimodal metaphor, systematic attention has been paid to three subtypes, the most common being a combination of visuals and written or spoken language, music, and sound (Forceville, 2016: 5).

\subsection{Methodological approaches to verbal and multimodal metaphorical patterns}

In recent years scholars proposed detailed metaphor identification procedures for both verbal discursive metaphors (e.g. Steen et al., 2010), recommending the use of dictionaries and reference sources to identify basic and contextual meanings and multimodal discursive metaphors (Tang, Quan, Zhu, 2020: 1045). In empirical studies on the one hand qualitative manual analysis was used and sometimes combined with annotation tools for linguistic annotations (e.g. web-based WebAnno) to be able to analyze bigger data sets (Steen et al., 2010). On the other hand, a corpus-based approach to metaphor analysis was established to study discourse patterns and variation in discourse patterns. These corpus-based ${ }^{5}$ studies have provided systematic metaphorical evidence retrieved from text surfaces on the basis of lexical sets (Stefanowitsch, 2006), (Ziem, 2010). In the corpus-based approach, metaphorical expressions are retrieved from unannotated corpora using lexical sets from source (e.g. water flow) and/or target domain (those migrating, migration) (Stefanowitsch, 2006). Bubenhofer (2009: 315), furthermore, provides linguistic evidence that $n-$ grams can also be metaphorically structured and display metaphorical potential (e.g. Kampf gegen $\mathrm{X}$ or fight against $\mathrm{X}$ with various $\mathrm{Xs}$ mapped as a problem that needs to be solved by fighting). Thus, by exploring n-grams, metaphorical multi-word

\footnotetext{
${ }^{4}$ Forceville (2016: 5) lists the following modes: spoken and written language, visuals, music, sound, gestures, smell, taste and touch, as possibly relevant in multimodal metaphors.

${ }^{5}$ For the differentiation between corpus-driven, corpus-assisted and corpus-based see for example Gredel (2015: 39).
} 
expressions can be retrieved from large corpora (Bubenhofer, 2009), (Gür-Şeker, $2019 b$ ). Several scholars argue that qualitative analysis of discursive phenomena such as metaphors are to be combined with quantitative measures, as the latter enable "concordancing through texts for key words, as well as comparative analysis between sources" (Fijavž, Fišer, 2020: 79) as well as languages (Gredel, 2015). Furthermore, implementation of relative frequencies and co-occurrence analysis of lexical items of source and/or target domain provide relevant corpus evidence for the analysis of metaphorical patterns and their variation.

In studies, combining corpus-based approach and linguistic discourse analysis (of metaphors) self-compiled topic-specific corpora or web-corpora are used, employing analytical programs such as AntConc, AntPConc, WordSmith or SketchEngine for verbal metaphor analyses and MAXQDA, ATLAS.ti or Nvivo for pictorial or video analysis of multimodal metaphors (Gür-Şeker, 2014: 588-589.). The corpus-based approach can further be used for cross-linguistic studies of discursive metaphorical expressions and their cross-linguistic variation: In this case, empirical studies either take one language as a starting point, using stranslation equivalents of these items « in other languages (Stefanowitsch, 2006: 69), (Gür-Șeker, 2019b) or metaphorical expressions are retrieved separately in each language corpus and compared afterwards (Semino, 2008), (Gredel, 2015).

\section{Corpus-based discourse linguistic analysis of multimodal metaphorical patterns in the migration discourse in Wikipedia}

In this study, we combine linguistic discourse metaphor analysis with a corpus-based approach, complementing qualitative and quantitative corpus evidence from Wikipedia migration corpus to explore a) predominant metaphorical patterns and their verbal and multimodal representations b) their use across Wikipedia articles and talk pages as well as in direct or reported statements.

\subsection{Corpus and methodology}

In order to explore the use of metaphorical expressions and their visual or multimodal representations in migration discourse, a topic-specific self-built corpus from the German language version of Wikipedia (articles and corresponding talk pages) was created. The free encyclopedia Wikipedia was selected as it represents a highly relevant source of information, i.e. the largest free online encyclopedia and one of the most consulted digital platforms (rank 7 and 13 of top sites in Germany and globally: Alexa 2021). As a multimodal and multilingual hypertext ${ }^{6}$ it furthermore represents a unique source for multimodal and cross-linguistic discourse analysis (Gredel, 2018). Wikipedia is a heterogeneous digital platform, consisting of:

a) objectively and collaboratively written, well structured multimodal articles, which represent the core of the free online encyclopedia and possibly the only broadly read part;

b) talk pages, which represent dialogical or interactive contributions of the socalled Wikipedians, authors of Wikipedia articles, discussing terminology and content-related improvements to the article;

c) user pages containing users conversations

d) revision history, where all changes (additions, deletions, edit wars) in the writing process of a given Wikipedia article can be viewed and analyzed.

\footnotetext{
${ }^{6}$ As a digital platform Wikipedia shows the following hypertextual characteristics: non-linearity, interactivity, multimodality, adaptivity and dynamics (Storrer, 2008: 318ff.).
}

XLinguae, Volume 14 Issue 2, April 2021, ISSN 1337-8384, eISSN 2453-711X 
The analyzed Wikipedia migration corpus consists of two German Wikipedia articles (a): Europäische Flüchtlingskrise (40,224 tokens) and Flüchtlingskrise in Deutschland 2015/2016 (32,085 tokens) as well as the corresponding talk pages (b) (162,535 and 94, 958 tokens), amounting to an overall total of 330,302 tokens $(72,809$ tokens/articles and 257,493 tokens/talk pages). Both articles refer to the increased immigration into the territory of the EU, which reached its peak in 2015/2016. This corpus represents a specific excerpt of the public discourse on the topic of refugee arrivals since 2015 .

Metaphor identification and analysis were performed as follows:

1) In the first qualitative step all topic-related metaphorical representations were analyzed manually only in the German Wikipedia article Europäische Flüchtlingskrise (40,224 tokens) and corresponding talk page for 2015 part I (29,900 tokens). Verbal metaphor identification was conducted according to MIPVU (Steen et al., 2010) using German online dictionary (Duden.de) and CCBD (co-occurrence database using data from the German reference corpus DeReKo) to identify basic and contextual meanings. In the case of multimodal metaphors, we identified and verbalized source and a target domain and mappings across the following two relevant modes ${ }^{7}$ : a) verbal mode: written language and b) visual mode: pictures, graphs, perspective (Forceville, 2016), (Tang, Quan, Zhu, 2020: 1045). Furthermore, we analyzed metaphor use across Wikipedia articles and talk pages separately, noting if metaphorical expressions were used in direct and reported statements of discourse agents.

2) In the quantitative step, we first explored verbal metaphors in the whole Wikipedia migration corpus (330,302 tokens), using the analytical program AntConc to search for identified metaphorical expressions from step 1 across articles and corresponding talk pages separately. For example, to find compounds and derivatives to the source lexeme flow (e.g. Strom, Flüchtlingsströme, strömen, strömend) in AntConc, we used the search term *strom*. We calculated relative frequencies of metaphorical expressions across articles and talk pages as well as their use in direct and reported statements. Furthermore, we explored adjectival collocates, which point to evaluative, discourse-specific associations and connotations, using collocation analysis in AntConc.

3) Finally, we analyzed pictures and graphs used in Wikipedia articles and talk pages manually to determine in which modes source and/or target were predominantly rendered in.

\section{Water flow/natural catastrophes and military/warfare as source domains}

The metaphor analysis sheds light on the use of metaphorical expressions and their multimodal representations in migration discourse since 2015 as constructed in Wikipedia. In both Wikipedia articles and the corresponding talk pages, the predominant proto-metaphors draw from two source domains: water flow/natural catastrophes and warfare/military. Discursive metaphorical patterns will be discussed separately as to their source domain as well as their use across Wikipedia articles and talk pages, respectively.

\footnotetext{
${ }^{7}$ Other modes such as aural (music, dubbing sound, natural sound) etc. do not play a role in the present study.
} 


\subsection{Metaphors from the source domain water flow/natural catastrophes}

In Wikipedia articles and corresponding talk pages the target domain (people migrating and migration) is predominantly structured in terms of water flow metaphors, referring to those migrating as a wave (Welle), flow (Strom), influx (Zustrom) and flood (Flut), who put pressure (Druck) on Europe and its borders.

\subsubsection{Qualitative analysis of multimodal metaphorical patterns}

Table 1 presents verbal and multimodal metaphors identified in the Wikipedia migration corpus, i.e. all identified types of metaphorical expressions (ME) with adjectival collocates, including metaphorical patterns with slots, an example of their cotextual use, a definition of the same lexical item from duden.de and its semantic preference in $\mathrm{CCBD}^{8}$. The last column shows multimodal manifestations.

Table 1: Identified verbal and multimodal metaphors drawing from the source domain water flow/natural catastrophes

\begin{tabular}{|c|c|c|c|c|}
\hline $\mathrm{ME}$ & $\begin{array}{l}\text { verbal metaphor in } \\
\text { context }\end{array}$ & $\begin{array}{l}\text { identified forms in } \\
\text { Wikipedia migration } \\
\text { corpus with adjectival } \\
\text { collocates }\end{array}$ & $\begin{array}{l}\text { Duden.de definition and } \\
\text { semantic preference in CCBD }\end{array}$ & $\begin{array}{l}\text { visual/multimodal } \\
\text { metaphor }\end{array}$ \\
\hline $\begin{array}{l}\text { Welle } \\
\text { (wave) }\end{array}$ & $\begin{array}{l}\text { Die drohende } \\
\text { Migrationswelle von } \\
\text { Süd nach Nord hat in } \\
\text { den EU-Institutionen } \\
\text { wie auch bei den } \\
\text { führenden EU-Staaten } \\
\text { zu einem } \\
\text { Kurswechsel geführt. }\end{array}$ & $\begin{array}{l}\text { = Welle, Flüchtlings- } \\
\text { welle(n), Migranten-, } \\
\text { Migrationswelle, } \\
\text { Fluchtwelle, } \\
\text { Gewaltwelle } \\
=\text { X in Wellen, eine } \\
\text { Welle/Wellen von X } \\
=\text { drohende }\end{array}$ & $\begin{array}{l}\text { Duden.de: } 1 \text {. der aus der } \\
\text { Wasseroberfläche sich für kurze } \\
\text { Zeit herauswölbende Teil bei } \\
\text { bewegtem Wasser; } 2 \text {. etwas, } \\
\text { was in großem Ausmaß bzw. in } \\
\text { mehr oder weniger dichter } \\
\text { Folge in Erscheinung tritt [und } \\
\text { sich ausbreitet, steigert] etc. } \\
\text { CCBD: emotions (positive and } \\
\text { negative), physical phenomena, } \\
\text { sea, protests, radio/ TV stations, } \\
\text { destructive natural phenomena }\end{array}$ & 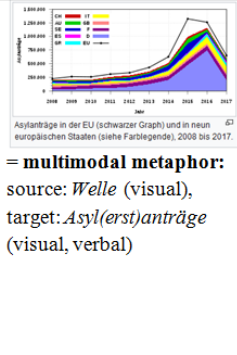 \\
\hline
\end{tabular}

\footnotetext{
${ }^{8}$ In CCBD we only examined those collocations which had the same syntactic properties as the identified forms in the analysed corpus.
}

XLinguae, Volume 14 Issue 2, April 2021, ISSN 1337-8384, eISSN 2453-711X 


\begin{tabular}{|c|c|c|c|c|}
\hline $\begin{array}{l}\text { Strom } \\
\text { (flow) }\end{array}$ & $\begin{array}{l}\text { Seit März } 2016 \\
\text { wandten die } 28 \text { EU- } \\
\text { Staaten den SGK } \\
\text { wieder an, um den } \\
\text {,irregulären } \\
\text { Migrantenstrom “ } \\
\text { auf der Balkanroute } \\
\text { zu beenden. }\end{array}$ & $\begin{array}{l}\text { = Ströme, } \\
\text { Migrationsströme, } \\
\text { Flüchtlingsströme, } \\
\text { Massenströme } \\
\text { = Strom an } \mathrm{X}(\mathrm{X}= \\
\text { Migranten, etc.) } \\
\text { = Migranten-, } \\
\text { Flüchtlings-, } \\
\text { Zuwanderungsstrom, } \\
\text { Hauptstrom der } \\
\text { Flüchtlinge } \\
\text { = strömen } \\
\text { = irreguläre, } \\
\text { wachsende, große, } \\
\text { unkontrollierte, neue }\end{array}$ & 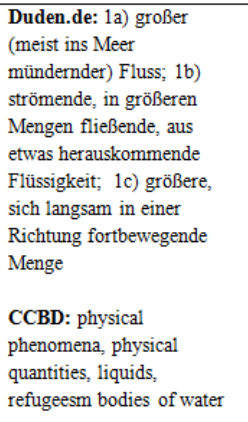 & $\begin{array}{l}\text { Fluchtinge nahe der Grenze } \\
\text { zwischen Serbien und Ungarn (25. } \\
\text { August 2015) } \\
\text { Co-text: Ausschluss unkon- } \\
\text { trollierter Migrationsströme } \\
\text { = multimodal metaphor: } \\
\text { Strom: source (visual, } \\
\text { verbal), Flüchtlinge: target } \\
\text { (visual, verbal) }\end{array}$ \\
\hline $\begin{array}{l}\text { Zustrom } \\
\text { (influx) }\end{array}$ & 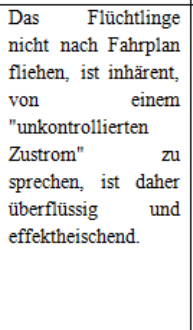 & $\begin{array}{l}\text { =Flüchtlings-, } \\
\text { Migrantenzustrom, } \\
\text { Zustrom, Zustrom der } \\
\text { Flüchtlinge, Zustrom } \\
\text { der Migranten } \\
\text { = Massenzustrom / } \\
\text { Zustrom von X (X = } \\
\text { Flüchtlinge, Asyl-, } \\
\text { Schutzsuchenden) } \\
\text { = massiver, } \\
\text { massenhafter, starker, } \\
\text { verstärkter }\end{array}$ & $\begin{array}{l}\text { Duden.de: 1. das Strömen } \\
\text { zu einer Stelle, einem Ort } \\
\text { hin (frisches Wasser, Luft); } \\
\text { 2. das Herbeiströmen, } \\
\text { Kommen an einen Ort } \\
\text { (Flüchtlinge); 3. Zulauf } \\
\text { CCBD: immigrants, } \\
\text { workers, money, } \\
\text { investments, tourists, } \\
\text { guests, natural resources } \\
\text { (air, water) }\end{array}$ & \\
\hline $\begin{array}{l}\text { Druck } \\
\text { (pressure) }\end{array}$ & $\begin{array}{l}\text { Zweitens sind mit } \\
\text { den Staaten an der } \\
\text { euro-päischen } \\
\text { Peripherie, } \\
\text { namentlich mit der } \\
\text { Türkei, Regelungen } \\
\text { zu treffen, die den } \\
\text { Druck der } \\
\text { Flüchtlinge auf die } \\
\text { Außengrenzen der } \\
\text { EU herabminderten. }\end{array}$ & $\begin{array}{l}\text { = Migrationsdruck auf } \\
\mathrm{X} \text { wächst (X= Europa, } \\
\text { EU), Migrationsdruck } \\
\text { an X (X = den EU- } \\
\text { Außengrenzen) } \\
\text { = Druck der } \\
\text { Flüchtlinge, Druck } \\
\text { durch Neueinkünte, } \\
\text { Druck seitens der } \\
\text { Zivilgesellschaft } \\
\text { = anhaltender, er- } \\
\text { heblicher, unver- } \\
\text { minderter, massiver, } \\
\text { wachsender, besonders } \\
\text { hoher }\end{array}$ & $\begin{array}{l}\text { Duden.de: 1. auf eine } \\
\text { Fläche wirkende Kraft } \\
\text { (Physik); } 2 \text {. Betätigung } \\
\text { durch Druck, das Drücken, } \\
\text { Gefühl des Drucks an einer } \\
\text { bestimmten Körperstelle; } 3 \text {. } \\
\text { gewaltsame, zwanghafte, } \\
\text { jemanden bedrängende } \\
\text { Einwirkung von außen } \\
\text { CCBD: people, politics, } \\
\text { economy, military, water }\end{array}$ & \\
\hline Flut (flood) & $\begin{array}{l}\text { Die Stimmen, die } \\
\text { vor einer "Flut von } \\
\text { Asylwerbern" und } \\
\text { vor "Flüchtlings- } \\
\text { wellen " warnen, } \\
\text { mehren sich. }\end{array}$ & $\begin{array}{l}\text { = überfluten, } \\
\text { = Flüchtlingsflut, } \\
\text { Asylantenflut, Flutwelle } \\
\text { = Flut von X }\end{array}$ & $\begin{array}{l}\text { Duden.de: } 1 \text {. im Wechsel } \\
\text { der Gezeiten ansteigender } \\
\text { Wasserstand; } 2 \text {. größere, } \\
\text { strömende Wassermasse } \\
\text { CCBD: water mass, water } \\
\text { flow, rules and laws, } \\
\text { communications forms } \\
\text { (letters, e-mails) }\end{array}$ & \\
\hline $\begin{array}{l}\text { eindäm- } \\
\text { men (to } \\
\text { dam) }\end{array}$ & $\begin{array}{lr}\text { Ziel ist } & \text { das } \\
\text { Training und } & \text { die } \\
\text { Ausrüstung } & \text { von } \\
\text { Grenzbeamten, } & \\
\text { damit diese } & \text { Fluchtbewegungen } \\
\text { über r ihre } \\
\text { Staatsgrenzen } \\
\text { hinweg besser } \\
\text { eindämmen können. }\end{array}$ & eindämmen & $\begin{array}{l}\text { Duden.de: 1. (fließendes } \\
\text { Wasser) durch Bauen eines } \\
\text { Dammes in eine bestimmte } \\
\text { Bahn, Richtung lenken oder } \\
\text { stauen; } 2 \text {. an der } \\
\text { Ausbreitung hindern } \\
\text { CCBD: violence and crime, } \\
\text { fire, water flow (flood), } \\
\text { corruption, (illegal) } \\
\text { migration }\end{array}$ & \\
\hline $\begin{array}{l}\text { über- } \\
\text { schwemmen } \\
\text { (flood) }\end{array}$ & $\begin{array}{lr}/ . . / & \text { internationale } \\
\text { Eliten } / . . . / \text { würden } \\
\text { insgeheim den Plan } \\
\text { verfolgen, r das } \\
\text { christliche Europa } \\
\text { mit muslimischen } \\
\text { Migranten ru } \\
\text { überschwemmen. }\end{array}$ & überschwemmen & $\begin{array}{l}\text { Duden.de: } 1 \text {. über etwas } \\
\text { strömen und es unter } \\
\text { Wasser setzen; } 2 \text {. in } \\
\text { überreichlichem Maß mit } \\
\text { etwas versehen } \\
\text { CCBD: larger groups o } \\
\text { people (tourists, refugees), } \\
\text { flowing water, water mass } \\
\text { (flood), products }\end{array}$ & Fig. 2a \\
\hline
\end{tabular}




\section{Verbal metaphors}

Before we reconstruct the metaphorical scenario from inferred metaphors and their cause-effect relations, let us first focus on individual metaphorical expressions, commenting on the mapping of semantic features from source to target, as well as their forms and adjectival collocates: Whereas in the case of both predominant metaphorical expressions, wave and flow, semantic features such as »a big, moving quantity or mass « are mapped to those migrating, wave, furthermore, mapped additional semantic features, »repetitive, spreading and increasing «, to target (Table 1). Another common metaphorical expression identified in the Wikipedia migration corpus is that of an influx, where the semantic feature »moving to/arriving at a place« is mapped to those migrating. In the corpus noun-noun-compounds with the root morphemes refugee, migrant or migration and asylum seeker as the first component and wave, flow or influx as the second prevail e.g. Migranten-, Flüchtlingsstrom, Flüchtlingswelle(n), Flüchtlings-, Migrantenzustrom. Moreover, metaphorical expressions of flow (Strom) have commonly been used in plural compounds (Migrations-, Flüchtlings- or Massenströme), emphasizing the quantity of flows from different directions and thus the complexity and size of recent migration. Apart from metaphorical compounds patterns with slots with metaphorical potential were identified: Strom an $X$ and Zustrom von $X$ (X = Migranten, Flüchtlinge, Asylsuchende). The cotextual analysis of adjectival collocates of these water flow metaphors, which points to the semantic preference in the discourse, furthermore suggests that the flow(s), wave(s) and influx of those migrating have been big, massive or increasing (große Ströme von Menschen, massiver Zustrom von Drittstaatenangehörigen, wachsende Migrationsströme), irregular or uncontrolled (irregulärer Migrantenstrom, unkontrollierte Migationsströme) and even threatening (drohende Flüchtlingswelle).

In the metaphorical scenario, these massive, increasing, and uncontrolled flows/waves of those migrating put pressure on Europe and its borders, another commonly used metaphorical expression in the migration discourse. The analysis of adjectival collocates of pressure metaphors, furthermore suggests that migratory pressure is persistent, considerable, undiminished and massive (anhaltender Migrationsdruck auf Europa, ein erheblicher Migrationsdruck, unverminderter Druck durch Neueinkünfte, massiver Druck). Thus those migrating represent a threat to flood and overflow the EU territory (muslimische Migranten überfluten das christliche Europa). In the following examples discourse participants see those migrating as a security risk:

(1) »Am 20. Dezember 2015 erklärte Frontex-Leiter Fabrice Leggeri die ,großen Ströme von Menschen, die derzeit unkontrolliert nach Europa einreisen', zum Sicherheitsrisiko.«(Wikipedia article 2021a)

Therefore (institutional) political discourse participants see the need to dam, control, regulate and reduce or even stop these moving masses of those migrating:

(2) »Außenminister Sebastian Kurz äußerte am gleichen Tag, es gebe eine starke Bereitschaft in Nordmazedonien und anderen Balkanstaaten, ,den Zustrom zu reduzieren, zu drosseln oder vielleicht sogar zu stoppen.' «(Wikipedia article 2021a)

In the following example, the Hungarian government speaks of a threatening refugee wave (drohende Flüchtlingswelle) and fear of terrorism to legitimize the detention of refugees in transit zones, which the UNHCR criticized as the violation of human rights (= securitization of migration).

XLinguae, Volume 14 Issue 2, April 2021, ISSN 1337-8384, eISSN 2453-711X 
(3) Ungarns Regierung begründete ihr Vorgehen mit einer angeblich drohenden Flüchtlingswelle, Terrorangst und der Weiterreise der meisten Asylantragssteller in andere Staaten. Das UNHCR kritisierte die Internierung als einen klaren Bruch von EU- und Völkerrecht. (Wikipedia article 2021a)

In the above examples, water flow metaphors are used in direct or reported statements of (institutional) discourse participants, refuting their arguments to introduce particular actions or measures. As these statements are taken from the media or institutional migration recommendations, the results suggest that Wikipedia authors reproduce water flow metaphors from newspapers and political discourse.

In Wikipedia migration corpus, water flow metaphors display various functions: Firstly, metaphors are used to present complex social phenomena such as the recent migration in a vivid and concise way (illustrative function). However, in migration discourse, as discussed above, their main function lies in evaluating groups of people and/or events and showing them from a particular perspective (perspectivation), focusing on particular characteristics and blending out the others. Moreover, the above examples (1-3) show that metaphors of water flow/natural catastrophes are also used to refute arguments of (institutional) discourse participants, arguing that those migrating represent a security risk for the EU states (Ex. 1), which legitimizes the actions taken by the EU governments, e.g. reintroducing border control within the EU (Ex. 3) or building a barbed wire. On talk pages, metaphors themselves become the topic of metadiscursive discussion. In their comments, users critically discuss and point out different aspects of metaphorical language use, particularly the use of water flow metaphors in relation to the recent migration since 2015. In the following comment the user points out that those migrating do not travel on a schedule, thus the metaphorical expression uncontrolled influx (unkontrolierter Zustrom) is not only redundant but also effect-seeking.

(4) Das Flüchtlinge nicht nach Fahrplan fliehen, ist inhärent, von einem "unkontrollierten Zustrom" zu sprechen, ist daher überflüssig und effektheischend.--Gonzo.Lubitsch (Wikipedia talk page 2021a)

Wikipedians sometimes use the argument from authority, as in the following example, where the Austrian linguist Ruth Wodak and her views on the effects of metaphor use in migration discourse on social awareness are cited. Professor Wodak points to the fact that all water flow/natural catastrophes metaphors, on the one hand, dehumanize those migrating and, on the other hand, place the Europeans in an insecure and powerless position. In this way professor, Wodak's citation is used as evidence to support the argument that a reflected and careful metaphor use is crucial when writing an encyclopedic article.

(5) \#7 Die Stimmen, die vor einer „Flut von Asylwerbern“ und vor „Flüchtlingswellen“ warnen, mehren sich. [...] „All diesen Metaphern ist gemein, dass sie sich auf Naturkatastrophen beziehen. Es wird suggeriert, dass man machtlos ist", sagt die Linguistin Wodak und erläutert, dass derartige Rhetorik eine „dehumanisierende Wirkung“ habe.“ Quelle: Wenn Menschen zur „Flut" werden. In: orf.at, 5.\&nbspAugust 2015. (Wikipedia talk page 2021a)

Whereas metadiscursive discussions can predominantly be found on talk pages, there is a text passage at the beginning of one Wikipedia article (2021a), describing the effects and implications metaphors have on those migrating and migration. Again the 
so-called argument from authority is used, citing Hannah von Grönheim, a scholar of social and political sciences.

\section{Multimodal metaphors}

Besides verbal metaphors, multimodal manifestations were identified primarily in Wikipedia articles (Fig. 1-3), as a result of an interplay of two relevant modes ${ }^{9}$ : a) verbal mode (written language) and b) visual mode (pictures, perspective (Fig. 1-2) and graphs (Fig. 3)) (Forceville 2016). According to subtexts in Fig. 1 photographs show refugees on a border bridge crossing the river Saalach at Salzburg (a) or on their way through Hungary to Austria (b). As those migrating are photographed in big groups from afar, their movement on the bridge or the road resembles a big river (source and target). In co-text verbal metaphors irregular migrant flow (den irregulären Migrantenstrom) (1a) and influx of refugees (Zustrom der Flüchtlinge) (1b) were identified. Both original and target were realized visually and verbally, reinforcing the image of those migrating as a flow or influx.

\section{Figure 1: Multimodal metaphors of flow and influx (Wikipedia 2021a)}

\begin{tabular}{|c|c|}
\hline $\begin{array}{l}\text { a) } \\
\text { Co-text: Seit März } 2016 \text { wandten die } 28 \\
\text { EU-Staaten den SGK }{ }^{10} \text { wieder an, um den } \\
\text { „irregulären Migrantenstrom“" auf der } \\
\text { Balkanroute zu beenden. (Wikipedia } \\
\text { article 2021a) } \\
\text { = multimodal metaphor: source: Strom } \\
\text { (visual, verbal), target: Migranten (visual, } \\
\text { verbal) }\end{array}$ & $\begin{array}{l}\text { Flüchtlinge auf der Grenzbrücke } \\
\text { zwischen Salzburg und Freilassing (23. } \\
\text { September 2015) }\end{array}$ \\
\hline $\begin{array}{l}\text { b) } \\
\text { Co-text: Orbáns Regierung lehnte eine } \\
\text { EU-Verteilquote für Flüchtlinge auch } \\
\text { Ende } 2017 \text { ab.: /.../ Sie erklärt den } \\
\text { Zustrom der Flüchtlinge nicht mit den } \\
\text { Push-Faktoren in den Herkunftsländern, } \\
\text { sondern mit der Verschwörungstheorie, } \\
\text { /.... (Wikipedia article 2020a) } \\
=\text { multimodal metaphor: source: } \\
\text { Zustrom (visual, verbal), target: } \\
\text { Flüchtlinge (visual, verbal) }\end{array}$ & $\begin{array}{l}\text { Flüchtlinge in Ungarn unterwegs } \\
\text { nach Österreich (4. September 2015) }\end{array}$ \\
\hline
\end{tabular}

Another variant represented multimodally is the metaphor of flood (Fig. 2), with visual components of the metaphor, typically showing those migrating at crowded railway stations and platforms in transit countries, waiting to continue their journey, preferably to Germany or Sweden. In 2a both source (flood) and target (refugees) are expressed visually and verbally: in the co-text to picture (2a) metaphorical expressions influx of refugees (Zustrom der Flüchtlinge) and Moslem migrants flooding Christian Europe (muslimische Migranten überschwemmen christliches

\footnotetext{
${ }^{9}$ Other modes such a aural (music, dubbing sound, natural sound) etc. do not play a role in the present study.

${ }^{10}$ SGK stands for Schengen Borders Code (2006), governing the movement of persons across borders.
}

XLinguae, Volume 14 Issue 2, April 2021, ISSN 1337-8384, eISSN 2453-711X 
Europa) can be found. In $2 \mathrm{~b}$ a multimodal flood metaphor with a visual component of a crowded Vienna railway station, similar to the negatively connoted multimodal metaphor in $2 \mathrm{a}$, is juxtaposed beside a verbal metaphor with a positive connotation, a wave of solidarity and helpfulness (eine Welle der Solidarität und Hilfsbereitschaft). In the co-text, both metaphors are placed in a cause-and-effect relationship, i.e. images of crowded railway stations in Hungary triggered the wave of solidarity in Vienna. As a consequence, $2 \mathrm{~b}$ stands out from the prevailing metaphorical scenario depicting those migrating as a threat, as refugees are shown as people in need of help, evoking solidarity and helpfulness on the side of EU citizens.

\section{Figure 2: Multimodal metaphors of flood (Wikipedia 2021a)}

\begin{tabular}{|c|c|}
\hline $\begin{array}{l}\text { a) } \\
\text { Co-text: Sie erklärt den Zustrom der } \\
\text { Flüchtlinge nicht mit den Push-Faktoren in den } \\
\text { Herkunftsländern, sondern mit der } \\
\text { Verschwörungstheorie, internationale Eliten } \\
\text { und namentlich der amerikanische Milliardär } \\
\text { George Soros würden insgeheim den Plan } \\
\text { verfolgen, das christliche Europa mit } \\
\text { muslimischen Migranten } \\
\text { überschwemmen. zu } \\
\text { = multimodal metaphor: source: überfluten, } \\
\text { Überflutung (visual, verbal), target: } \\
\text { Flüchtlinge, Migranten (visual, verbal) }\end{array}$ & $\begin{array}{l}\text { Flüchtlinge am Budapest Keleti } \\
\text { pályaudvar (4. September 2015) }\end{array}$ \\
\hline $\begin{array}{l}\text { b) } \\
\text { Co-text: Die Bilder vom Budapester } \\
\text { Ostbahnhof lösten eine Welle der Solidarität } \\
\text { und Hilfsbereitschaft aus; die am Wiener } \\
\text { Westbahnhof ankommenden Flüchtlinge } \\
\text { wurden mit Applaus begrüßt und mit } \\
\text { Hilfsgütern versorgt. } \\
\text { = multimodal metaphor: source: überfluten, } \\
\text { Überflutung (visual), target: Migranten (visual, } \\
\text { verbal) } \\
=\text { verbal metaphor: welle der Solidarität und } \\
\text { Hilfsbereitschaft }\end{array}$ & $\begin{array}{l}\text { Migranten am Wien Westbahnhof } \\
\text { vor der Fahrt nach Deutschland, } 5 . \\
\text { September } 2015^{[436]}\end{array}$ \\
\hline
\end{tabular}

Multimodal metaphors of water flow can furthermore be realized with graphs as visual components in Wikipedia articles: Both graphs in Figure 3 show the number of asylum seekers between 2008-2017 (3a) and 2019-2010 (3b) in different EU states, both peaking in 2016 and 2015 respectively: The statistical trend of asylum seekers resembles a wave, based on the analogy to physical wave forms. 
Figure 3: Multimodal metaphors of wave (Wikipedia 2021a)

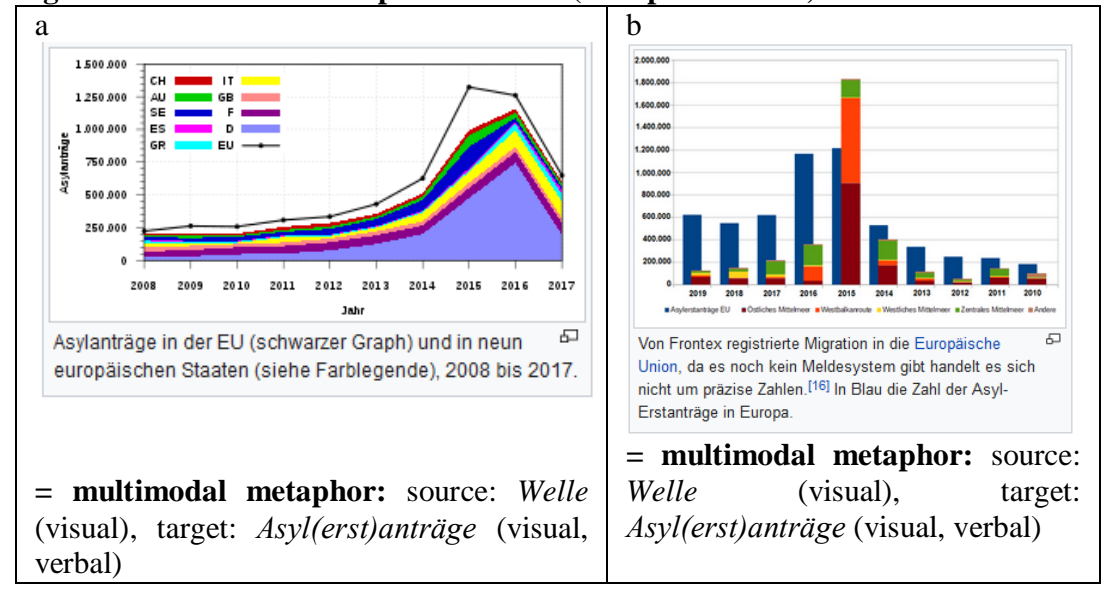

The patterning of water flow metaphors across Wikipedia articles and talk pages is in multimodal metaphors extended, elaborated, and reinforced in visual mode (images and graphs depicting those migrating in big groups from afar). These visual components of multimodal metaphors do not merely have an illustrative function, as they reinforce the functions identified in verbal metaphors: argumentative and persuasive function (Gredel, 2018a). Unlike verbal metaphors, multimodal metaphors are rarely discussed in a metadiscursive way. In a single case, a discussion of a photograph (Fig. 1c) suggests that the use of pictures and their subtexts is well premeditated and as such, has a discourse-constitutive function.

\subsubsection{Quantitative aspects of discursive metaphors in Wikipedia articles and talk pages}

Table 2 presents frequencies of metaphorical expressions and multimodal metaphors in Wikipedia articles and talk pages, respectively. Relative frequencies of verbal metaphors suggest that wave, flow, influx and pressure represent the predominant metaphorical expressions in that order, often additionally manifested multimodally. In general, these verbal metaphors show a relatively high frequency in both articles and talk pages (1.5-1.0 per 10,000 tokens) if compared to related research on the use of water flow metaphors in migration discourse on Slovenian news web portal in 2015 during the increased arrival of refugees (2.05 per 10,000 tokens) (Fijavž, Fišer, 2020: 73). In Wikipedia articles, verbal metaphors are frequently used in direct or reported statements of (institutional) discourse participants (0.8-0.3 per 10,000 tokens) to refute their arguments. This suggests that Wikipedia authors often reproduce water flow metaphors from newspapers and political discourse (Fijavž, Fišer, 2020: 58). 
Table 2: Verbal and multimodal representations of metaphors in Wikipedia articles and corresponding talk pages.

\begin{tabular}{|c|c|c|c|c|c|c|}
\hline & \multicolumn{3}{|c|}{$\begin{array}{l}\text { metaphors in } \\
\text { Wikipedia articles }\end{array}$} & \multicolumn{3}{|c|}{$\begin{array}{l}\text { metaphors in talk } \\
\text { pages }\end{array}$} \\
\hline & \multicolumn{2}{|c|}{ verbal metaphors } & $\begin{array}{l}\text { multimodal } \\
\text { metaphors }\end{array}$ & & $\begin{array}{l}\text { verbal } \\
\text { metaphors }\end{array}$ & $\begin{array}{l}\text { multimod } \\
\text { al }\end{array}$ \\
\hline & $\begin{array}{l}\text { types/ } \\
\text { tokens }\end{array}$ & $\begin{array}{l}\text { el. freq. of } \\
\text { ll } \\
\mathrm{ORS}^{11} \text { ) } \text { (in } \\
10,000 \\
\text { okens }\end{array}$ & & $\begin{array}{l}\text { types/ } \\
\text { tokens }\end{array}$ & 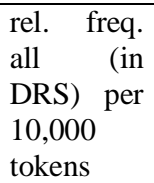 & \\
\hline $\begin{array}{l}\text { Welle } \\
\text { (wave) }\end{array}$ & $\begin{array}{ll}5 / \\
11\end{array}$ & $1.5(0.6)$ & $0 / 3$ & $5 / 40$ & $1.6(0.1)$ & $\mathbf{0} / \mathbf{0}$ \\
\hline $\begin{array}{l}\text { Strom } \\
\text { (flow) }\end{array}$ & $\begin{array}{ll}3 & I \\
8\end{array}$ & $1.1(0.8)$ & $0 / 5$ & $7 / 30$ & $1.1(0.08)$ & $\mathbf{0} / 0$ \\
\hline $\begin{array}{l}\text { Zustrom } \\
\text { (influx) }\end{array}$ & $\begin{array}{ll}4 & / \\
7 & \end{array}$ & $1(0.6)$ & $\mathbf{0} / \mathbf{1}$ & $7 / 25$ & $1(0.08)$ & $\mathbf{0} / \mathbf{0}$ \\
\hline $\begin{array}{l}\text { Druck } \\
\text { (pressure) }\end{array}$ & $\begin{array}{ll}4 & I \\
9\end{array}$ & $1.2(0.3)$ & $\mathbf{0} / 1$ & $4 / 8$ & $0.3(0.04)$ & $0 / 0$ \\
\hline $\begin{array}{l}\text { Flut } \\
\text { (flood) }\end{array}$ & $\begin{array}{ll}1 & / \\
1 & \end{array}$ & $0.1(0.1)$ & $1 / 0$ & $6 / 8$ & $0.3(0)$ & $0 / 0$ \\
\hline $\begin{array}{l}\text { Damm } \\
\text { (dam) }\end{array}$ & \begin{tabular}{ll|}
1 & $/$ \\
1 &
\end{tabular} & $0.3(0)$ & $0 / 0$ & $1 / 1$ & $0.04(0)$ & $0 / 0$ \\
\hline $\begin{array}{l}\text { Schwem- } \\
\text { me }\end{array}$ & $\begin{array}{ll}1 & / \\
1 & \end{array}$ & $0.3(0)$ & $0 / 0$ & $2 / 2$ & $0.08(0)$ & $0 / 0$ \\
\hline $\begin{array}{l}\text { Tsunami } \\
\text { (tsunami) }\end{array}$ & $\begin{array}{ll}0 & / \\
0 & \end{array}$ & $0(0)$ & $0 / 0$ & $1 / 2$ & $0.08(0)$ & $0 / 0$ \\
\hline
\end{tabular}

\subsection{Metaphors from the source domain warfare/military}

The analyzed Wikipedia migration corpus contains several examples where warfare/military serve as source domain. Besides those migrating smugglers, illegal migration and the causes of flight and migration represent the target domain.

\subsubsection{Qualitative analysis of multimodal metaphorical patterns}

Table 3 presents all identified types of metaphorical expressions with adjectival collocates, including structural patterns with slots, an example of contextual use, a definition of the same lexical item from duden.de, and its semantic preference in CCBD. The last column shows and multimodal manifestations.

${ }^{11}$ Direct or reported statements. 
Table 3: Identified verbal and multimodal metaphors drawing from the source domain warfare/military

\begin{tabular}{|c|c|c|c|c|}
\hline $\begin{array}{l}\text { source } \\
\text { domain }\end{array}$ & $\begin{array}{l}\text { verbal metaphor in } \\
\text { context }\end{array}$ & $\begin{array}{l}\text { identified forms in } \\
\text { Wikipedia migration } \\
\text { corpus with adjectival } \\
\text { collocates }\end{array}$ & $\begin{array}{l}\text { Duden de definition and semantic } \\
\text { preference in CCBD }\end{array}$ & multimodal manifestations \\
\hline Kampf & $\begin{array}{l}\text { Auch einigte man } \\
\text { sich, den Etat des } \\
\text { Auswärtigen Amts } \\
\text { um jährlich } 400 \\
\text { Millionen Euro zu } \\
\text { erhöhen, um } \\
\text { Fluchtursachen zu } \\
\text { bekämpfen. }\end{array}$ & $\begin{array}{l}\text { = Kampf gegen X }(\mathrm{X}= \\
\text { Flüchtlinge, Schlepper, } \\
\text { Schleuser }) \\
\text { = zur Bekämpfung von } \\
\mathrm{X}(\mathrm{X}=\text { Fluchtursachen, } \\
\text { Ursachen) } \\
\text { = Migrations-, } \\
\text { Schleuserbekämpfung, } \\
\text { Bekämpfungsansatz, } \\
\text { Anti-Terror-Kampf, } \\
\text { Vorkämpfer } \\
\text { = bekämpfen, } \\
\text { ankämpfen, kämpfen } \\
\text { mit }\end{array}$ & $\begin{array}{l}\text { Duden.de: } 1 \text {. größere militärische } \\
\text { Auseinandersetzung feindlicher } \\
\text { Truppen; } 2 \text {. handgreiflich, auch } \\
\text { mit Waffen geführte, heftige } \\
\text { Auseinandersetzung zwischen } \\
\text { zwei oder mehreren } \\
\text { [persönlichen] Gegnern; } 3 \text {. } \\
\text { fortgesetzte angestrengte } \\
\text { Bemühung zur Erreichung oder } \\
\text { Verhinderung von etwas } \\
\text { CCBD: terror(ism), corruption, } \\
\text { crime, violence, militant groups } \\
\text { (mafia, guerilla, the Taliban) } \\
\text { unemployment, poverty, inflation, } \\
\text { immigration, illness }\end{array}$ & 7 \\
\hline Sturm & $\begin{array}{l}\text { Der Versuch der } \\
\text { Grenzstürmung } \\
\text { folgte einem } \\
\text { Gerücht, die } \\
\text { mazedonische } \\
\text { Grenze sei wieder } \\
\text { offen. }\end{array}$ & $\begin{array}{l}\text { = Sturm, } \\
\text { Flüchtlingssturm, } \\
\text { Flüchtlinge stürmen, } \\
\text { Grenzstürmung }\end{array}$ & $\begin{array}{l}\text { Duden.de (Sturm): 1. sehr } \\
\text { heftiger, starker Wind; } 2 \text {. heftiger, } \\
\text { schnell vorgetragener Angriff mit } \\
\text { dem Ziel, den [völlig } \\
\text { unvorbereiteten] Gegner zu } \\
\text { überraschen, seine Verteidigung } \\
\text { zu durchbrechen } \\
\text { CCBD: police, larger groups of } \\
\text { people (fans, protesters), soldiers } \\
\text { and armed people }\end{array}$ & \\
\hline Ansturm & $\begin{array}{l}\text { /... etwa } 600 \\
\text { Afrikaner gelangten } \\
\text { auf spanisches } \\
\text { Terrain. Es war der } \\
\text { größte Ansturm der } \\
\text { vergangenen Jahre. }\end{array}$ & $\begin{array}{l}\text { = großer Ansturm, } \\
\text { Migranten-, } \\
\text { Flüchtlingsansturm }\end{array}$ & $\begin{array}{l}\text { Duden.de (Ansturm): } 1 \text {. das } \\
\text { Heranstürmen; stürmisches } \\
\text { Andrängen; } 2 \text {. großer Andrang } \\
\text { CCBD: larger groups of people } \\
\text { (visitors, pilgrims, refugees, fans, } \\
\text { tourists, students), the media }\end{array}$ & \\
\hline Kolonne & $\begin{array}{l}\text { Subtext: Eine } \\
\text { Flüchtlingskolonne } \\
\text { in Slowenienm } \\
\text { begleitet von Militär } \\
\text { und Polizei. }\end{array}$ & $\begin{array}{l}\text { = Flüchtlingskolonne, } \\
\text { Marschkolonne }\end{array}$ & $\begin{array}{l}\text { Duden.de: 1a) in langer } \\
\text { Formation marschierende Truppe; } \\
\text { 1b) lange Formation in } \\
\text { gleichmäßigen Abständen } \\
\text { hintereinanderfahrender } \\
\text { [militärischer] Fahrzeuge; 1c) in } \\
\text { langer Formation sich } \\
\text { fortbewegende Gruppe von } \\
\text { Menschen } \\
\text { CCBD: soldiers, refugees, } \\
\text { military vehicles (tanks), vehicles } \\
\text { (cars, truks) }\end{array}$ & $\begin{array}{l}\text { Eine Flochtingskolonne in } \\
\text { Slowenien, begleitet von Mirtar und } \\
\text { Polizei, 22. Oktober } 2015 \\
\text { = multimodal metaphor: } \\
\text { source: Kolonne (visual, } \\
\text { verbal), target: Flüchtlinge } \\
\text { (visual, verbal) }\end{array}$ \\
\hline
\end{tabular}

The Wikipedia migration discourse has predominantly been structured by metaphorical expressions of the fight (Bekämpfung, bekämpfen). Semantic features such as »military or violent/severe confrontation with an enemy« and »strenuous efforts to prevent sth.« are mapped to target the efforts of (institutional) discourse participants to stop smugglers (Schleuserbekämpfung, Schleuserbanden bekämpfen, ankämpfen, kämpfen mit) and to prevent illegal migration (Illegalität bekämpfen). Besides compounds and verbs structural patterns with slots were identified: fight against X (Kampf gegen X) and combating X (zur Bekämpfung von X) (X = Schleuser, Schlepper, Flüchtlinge or smugglers and refugees). In this metaphorical scenario smugglers are referred to as criminals and illegal migration as a criminal act of an enemy. It is the institutional discourse participants, e.g. Europol and Frontext, who see the need to fight smugglers:

(6) Zur Bekämpfung der Schleusungskriminalität baute Europol ein neues Zentrum auf. (Wikipedia article 2021b) 
Political discourse participants furthermore stress the importance to fight causes of flight and migration. In the following example, Angela Merkel considers the fight against causes of fight as part of her European-Turkish solution.

(7) In ihrer Regierungserklärung am 17. Februar 2016 sagte die Bundeskanzlerin, sie werde sich weiterhin für eine europäischtürkische Lösung in der Flüchtlingsfrage einsetzen. /.../ Dieses Ziel soll durch die Bekämpfung der Fluchtursachen, /.../ und einen geordneten und gesteuerten Flüchtlingszuzug erreicht werden. (Wikipedia article 2021b)

In the following example, humanitarian organizations point out that the fight against smugglers equals the fight against refugees. Thus not only smugglers but also those migrating are mapped as enemies.

(8) Einige humanitäre Organisationen kritisieren, der auf Schlepper in Küstennähe begrenzte Frontex-Auftrag komme einem Kampf gegen Flüchtlinge gleich. (Wikipedia article 2021a)

On talk pages, fight against refugees is further reinforced by the metaphor war against refugees.

(9) »Weil die EU-Operation Triton von 2014, aus der Frontex hervorging, vorrangig Schlepper in Küstennähe bekämpfte, aber keine Seenotrettung betrieb, sprach die NGO Pro Asyl von einem „Krieg gegen Flüchtlinge" «(Wikipedia talk page 2021b)

In the Wikipedia corpus, the intended metaphor of those migrating as enemies is reinforced through metaphorical compounds with the root morpheme column, storming or onslaught as the second component, and verbs such as to march, to attack, to escort. In this metaphorical scenario, those migrating are constructed as enemies, storming European borders (Grenzstürmung) and attacking border control officers. Their onslaughts (Ansturm), moreover, cause difficulties in transit countries. However, it is their marching into and through the EU territory in columns (Marsch-, Flüchtlingskolonne), sometimes escorted by police and military vehicles, that is reinforced multimodally (Table 3: Kolonne). Consequently, the Austrian interior minister Mikl-Leitner calls for fortress Europe (Festung Europa) to be built, another warfare metaphor suggesting that Europe is being attacked by enemies and is at war. A fortress is namely a stronghold, constructed for strategic reasons and for protection in war and similar situations.

(10) Unter dem unverminderten Druck durch Neuankünfte aus Slowenien erklärte Österreichs Innenministerin Mikl-Leitner, man müsse an einer „Festung Europa“ bauen. (Wikipedia article 2021b)

In Wikipedia article Flüchtlingskrise in Deutschland 2015/2016 fortress Europe is contrasted with Australia, New Zeeland, and Canada, referred to as fortresses of competence (Kompetenzfestungen), seeing migration as competition for people with professional potential. Due to its poorly qualified migrants, Europe is losing the competition for highly qualified specialists.

Like water flow metaphors, metaphorical patterns that draw from the source domain of warfare/military are mainly used to evaluate groups of people, their actions and/or events by focusing on particular characteristics and blending out the others 
(perspectivation). Though not as common as the water flow metaphors, warfare metaphors are also used to refute arguments of (institutional) discourse participants (Ex. 8, 10). On talk pages, however, metaphor use itself becomes the topic of discussion. In their comments, users discuss different aspects of metaphorical language use in relation to the recent migration since 2015, in some cases using the argument from authority. On talk pages, a longer passage entitled Sprachgebrauch in der Berichterstattung über geflüchtete Menschen (Language use in media coverage on those migrating) can be found:

(11) Auffällig in der Berichterstattung ist zudem, dass Metaphern verwendet werden, um die Vorstellungskraft anzuregen, Sachverhalte zu verbildlichen, Aussagen zu vereinfachen sowie ihnen Nachdruck zu verleihen. Insbesondere die Bereiche Militär, Wirtschaft, Krieg und Naturkatastrophen finden Verwendung. (Wikipedia talk page 2021b)

\subsubsection{Quantitative aspects of discursive metaphors in Wikipedia articles and talk pages}

Table 4 presents frequencies of warfare metaphors and their rare multimodal manifestations in Wikipedia articles and talk pages, respectively. Whereas the relative frequency of 2.9 per 10,000 tokens of the predominant metaphorical expression fight (Kampf) in Wikipedia articles even exceeds that of wave (Welle), the other warfare metaphors are less commonly used. The greatest difference between both protometaphors water flow and warfare is, however, the lack of multimodal manifestations of warfare metaphors. Besides fight, metaphorical expressions such as storm, attack, and fortress were relatively common in Wikipedia articles as well as storm, war, marching, and column on corresponding talk pages. Furthermore, warfare metaphors are relatively rarely used in direct or reported statements of (institutional) discourse participants if compared to water flow metaphors.

Table 4: Metaphorical representations in Wikipedia articles and talk pages

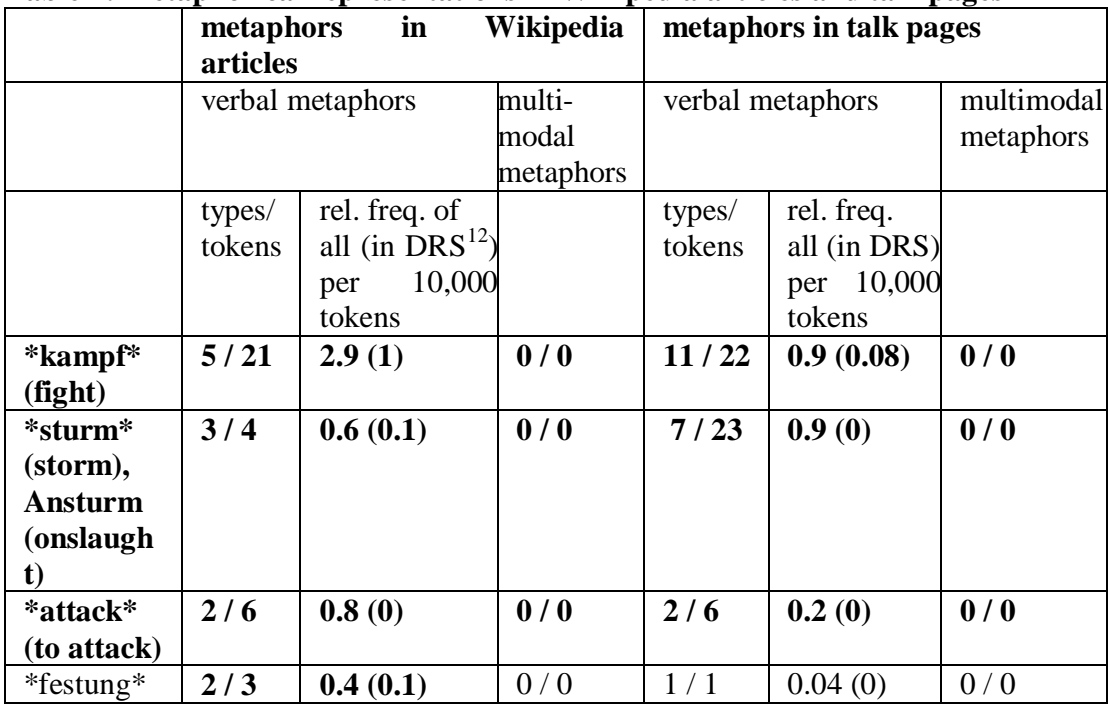

\footnotetext{
${ }^{12}$ Direct or reported statements.
}

XLinguae, Volume 14 Issue 2, April 2021, ISSN 1337-8384, eISSN 2453-711X 


\begin{tabular}{|l|l|l|l|l|l|l|}
\hline (fortress) & & & & & & \\
\hline $\begin{array}{l}\text { *krieg* } \\
\text { (war) }\end{array}$ & $0 / 0$ & $0(0)$ & $0 / 0$ & $\mathbf{1} / \mathbf{5}$ & $\mathbf{0 . 2}(\mathbf{0 )}$ & $0 / 0$ \\
\hline $\begin{array}{l}\text { *marsch* } \\
\text { (to march) }\end{array}$ & $1 / 1$ & $0.1(0.1)$ & $0 / 0$ & $\mathbf{3 / 5}$ & $\mathbf{0 . 2}(\mathbf{0 )}$ & $0 / 0$ \\
\hline $\begin{array}{l}\text { *kolonne* } \\
\text { (column) }\end{array}$ & $1 / 1$ & $0.1(0)$ & $0 / 1$ & $\mathbf{3 / 5}$ & $\mathbf{0 . 2}(\mathbf{0 )}$ & $\mathbf{0 / 1}$ \\
\hline $\begin{array}{l}\text { *belagern* } \\
\text { (to } \\
\text { besiege) }\end{array}$ & $0 / 0$ & $0(0)$ & $0 / 0$ & $1 / 1$ & $0.04(0)$ & $0 / 0$ \\
\hline $\begin{array}{l}\text { *eskortie- } \\
\text { ren* (to } \\
\text { escort) }\end{array}$ & $1 / 1$ & $0.1(0)$ & $0 / 0$ & $0 / 0$ & $0(0)$ & $0 / 0$ \\
\hline $\begin{array}{l}\text { *invasion* } \\
\text { (invasion) }\end{array}$ & $0 / 0$ & $0(0)$ & $0 / 0$ & $1 / 1$ & $0.04(0)$ & $0 / 0$ \\
\hline
\end{tabular}

\section{Conclusion}

In this study, we combine linguistic discourse metaphor analysis with a corpus-based approach, complementing qualitative and quantitative corpus evidence from Wikipedia migration corpus to explore verbal and multimodal metaphorical patterns. Lexems drawing from the predominant source domains water flow/natural catastrophes and warfare/military were mostly used in a metaphorical sense in the Wikipedia migration corpus. The most common verbal metaphorical expressions from the source domain water flow/natural catastrophes were wave (Flüchtlings-, Migrantenwelle) and flow (Flüchtlings-, Migrations-, Migrantenstrom), followed by influx and pressure (Migrationsdruck). Though in German Wikipedia metaphorical compounds prevail, the mentioned lexemes from the source domain water flow also constitute metaphorical patterns with slots: $X$ in Wellen, eine Welle/Wellen von $X$, Strom der $X$, Strom von $X$, Zustrom der $X$, Zustrom von $X$ with $X$ fillers such as refugees (Flüchtlinge), migrants (Migranten), those migrating (Flüchtende) or asylum seekers (Asylwerber). Adjectival collocates (big, massive, increasing, irregular or uncontrolled), which point to the semantic preference in the discourse, reinforce a picture of those migrating as a threatening water mass with potentially devastating consequences for the society and its welfare, building up pressure on the EU territory and its borders. Although less frequently used, the following metaphorical expressions from the source domain warfare/military were identified: fight against $\mathrm{X}$, combating of $\mathrm{X}$ or to fight (Kampf gegen Flüchtlinge/Schlepper, Schleuser), storm (Flüchtlingssturm), onslaught (Ansturm, Flüchtlings-, Migrantenansturm), to march (marschieren, Marschkolonne) or war against refugees (Krige gegen Flüchtlinge). Martial metaphors on the one hand, like metaphors of water flow/natural catastrophes, refer to those migrating, picturing them as militant enemies, who are storming fortress Europe (Festung Europa) and must thus be fought against (Krige gegen Flüchtlinge). On the other hand, martial metaphors refer to smugglers, assisting refugees in entering the EU illegally (Kampf gegen Schleppern/Schleusern, Schleusebekämpfung) or migration itself (Migrationsbekämpfung).

The patterning of water flow metaphors across Wikipedia articles and talk pages is in multimodal metaphors extended, elaborated, and reinforced in visual mode (images and graphs depicting those migrating in big groups from afar). These visual components of multimodal metaphors, primarily used in articles, do not merely have the illustrative function, as they reinforce the image of those migrating as a flow, wave, influx, and more rarely as a marching column. The predominant use of multimodal metaphors in articles represents only one of several differences between 
objective and content-oriented Wikipedia articles on the one hand and on dialogical and often terminology-oriented talk pages on the other. For example, almost half of all aquatic and martial metaphorical expressions in Wikipedia articles were used in direct or reported statements of (institutional) discourse participants to refute their arguments and thus legitimize their actions (e.g. introducing border control within the EU). Like in related studies, this finding points to the fact that (metaphorical) language of political discourse participants is also uncritically reproduced in Wikipedia articles. In the other cases, aquatic and martial metaphorical expressions were mostly used by the Wikipedians to describe those migrating and related topics. On talk pages, however, metaphors were primarily a subject of metadiscursive disputes, i.e. critical discussions on the use of adequate metaphorical expressions. Apart from these discussions, where arguments from authority were commonly used, instances of metaphor use as »counter-speech against securitization« were found.

\section{Bibliographic references}

ALEXA, 2021. The top 500 websites worldwide. Available online: https://www.alexa.com/topsites (11.1.2021)

ANTHONY, L. 2020. AntConc (Version 3.5.9) [Computer Software]. Tokyo, Japan: Waseda University. Available online: https://www.laurenceanthony.net/software

BAKER, P. - McENERY, A. 2005. A corpus-based approach to discourses of refugees and asylum seekers in UN and newspaper texts. In: Language and Politics vol. 4, n. 2, pp. 197-226. ISSN 1569-2159

BLACK, M. 1983. Die Metapher. In: A. Haverkamp (ed.), Theorie der Metapher. Darmstadt: Wissenschaftliche Buchgesellschaft, pp. 55-79 (Wege der Forschung 389). ISBN: 3534131525

BRANDT, C. 2004. Metapher und Experiment. Braunschweig: Wallstein Verlag. ISBN 978-3-89244-806-8

OOKE, K. 1997. Die 'Invasion' aus den 'Armenhäusern Europas'. Metaphern im Einwanderungsdiskurs. In: M. Jung, M. Wengeler, K. Böke (eds.): Die Sprache des Migrationsdiskurses. Das Reden über 'Ausländer' in Medien, Politik und Alltag. Opladen: Westdeutscher Verlag, pp. 164-193.

BOKE, K. - JUNG, M. - NIEHR, Th.- WENGELER, M. 2000. Vergleichende Diskurslinguistik. Überlegungen zur Analyse national heterogener Textkorpora. In: Th. Niehr, K. Böke (eds.), Einwanderungsdiskurse. Vergleichende diskurslinguistische Studien. Opladen: Westdeutscher Verlag, pp. 11-36.

BUBENHOFER, N. 2009. Sprachgebrauchsmuster. Korpuslinguistik als Methode der Diskurs- und Kulturanalyse. Berlin, New York: De Gruyter (= Sprache und Wissen 4). ISBN: 978-3-11-021584-7

BUSSE, D. 1987. Historische Semantik. Stuttgart: Cotta.

BUSSE, D. - TEUBERT, W. 1994. Ist Diskurs ein sprachwissenschaftliches Objekt? Zur Methodenfrage der historischen Semantik. In: D. Busse, F. Hermanns, W. Teubert (Eds.): Begriffsgeschichte und Diskursgeschichte. Methodenfragen und Forschungsergebnisse der historischen Semantik. Opladen: Westdeutscher Verlag, pp. 10-28. ISBN-10: 3531126032

DEIGNAN, A. 2005. Metaphor and corpus linguistics. Amsterdam: John Benjamins Publishing Company. ISBN 9789027238924

FIJAVZ, Z. - FISER, D. 2020. Corpus-assisted analysis of water flow metaphors in Slovene online news migration discourse of 2015. In: D. Fiser, Ph. Smith (eds.), The dark side of digital platforms: linguistic investigations of socially unacceptable online discourse practices, 1st ed. Ljubljana: University Press, Faculty of Arts, pp. 56-84. (Translation studies and applied linguistics) ISSN 2335-335X 
FORCEVILLE, Ch. 2016. Pictorial and multimodal metaphor. In: N.-M. Klug, H. Stöckl (eds.), Handbuch Sprache im multimodalen Kontext. Berlin, München, Boston: de Gruyter, pp. 241-260. ISBN: 978-3-11-029574-0

FORCEVILLE, Ch. 2006. Non-verbal and multimodal metaphor in a cognitivist framework: Agendas for research. In: G. Kristiansen et al. (eds.), Cognitive Linguistics: Current Applications and Future Perspectives. Berlin: de Gruyter, pp. 379-402. ISSN: 1861-4078

FOUCAULT, M. 1972. The Archeology of Knowledge. London: Tavistock.

GREDEL, E. 2018. Metaphorische Muster zur Europäischen Integration in verschiedenen Sprachversionen der Wikipedia: die Online-Enzyklopädie als Ressource zum Sprach- und Kulturvergleich. In: E. Gredel, H. Kämper, R. Mell, J. Polajnar (eds.).

GREDEL, E. 2015. Metaphorical Patterns and the Subprime Mortgage Crisis: Towards Cross-linguistics, Discourse-Specific and N-Gram-Based Dictionaries for Sentiment Analysis. In: Studies in Communication Sciences, vol. 15, n.1, pp. 37-44. ISSN 1424-4896

GREDEL, E. 2014. Diskursdynamiken. Metaphorische Muster zum Diskursobjekt Virus. Berlin: de Gruyter. DOI: https://doi.org/10.1515/9783110366754

GREDEL, E. - KAMPER, H. - MELL, R. - POLAJNAR, J. (eds.). 2018. Diskurs kontrastiv : Diskurslinguistik als Methode zur Erfassung transnationaler und sprachübergreifender Diskursrealitäten. Bremen: Hempen. 2018. (Sprache - Politik Gesellschaft 23). ISSN: 0771-3703

GUR-SEKER, D. 2019a. Exklusionsstrategien in rechtspopulistischen Reden. Eine sprachkritische Annäherung mit Fokus auf Nomination, Prädikation und Metapherngebrauch im Diskurs über Migranten. In: J. Schiewe, Th. Niehr, S. Moraldo (eds.): Sprach(kritik)kompetenz als Mittel demokratischer Willensbildung. Sprachliche In- und Exklusionsstrategien als gesellschaftliche Herausforderung. Bremen: Hempen Verlag, pp. 79-98.

GUR-SEKER, D. 2019b. Kontrastive Diskurslinguistik und methodische Perspektivierungen auf Online-Diskurse. In: G. Rocco,E. Schaffroth (eds.): Methoden der vergleichenden Diskurslinguistik. Germanistisch-romanistische Beiträge zur Methodenreflexion und Forschungspraxis. Berlin: Peter Lang, pp. 217-234. DOI: https://doi.org/10.3726/b15355

GUR-SEKER, D. 2014. Zur Verwendung von Korpora in der Diskurslinguistik. In: J. Angermuller et al. (eds.): Kompendium der interdisziplinären Diskursforschung. Bielefeld: transcript, pp. 583-603. ISBN: 978-3-8394-2722-4

GUR-ŞEKER, D. 2012. Transnationale Diskurslinguistik. Theorie und Methodik am Beispiel des sicherheitspolitischen Diskurses über die EU-Verfassung in Deutschland, Großbritannien und der Türkei. Bremen: Hempen. (Sprache- Politik - Gesellschaft 6). ISBN: 78-3-934106-98-7

ISSEL-DOMBERT, S - WIEDERS-LOHEAC, A. 2018. Auf Flüchtlingswellen surft man nicht vor Lampedusa - Zur Metaphorik des öffentlichen Diskurses zur Flüchtlingskrise Italiens. In: metaphern.de vol. 28, pp. 77-97.

KLUG, N.-M. 2018. „Wenn schlüsseltexte Bilder sind. Aspekte von Intertextualität in Presse und öffentlichem Raum.“ In: S. Pappert, S. Michel (eds.), Multimodale Kommunikation in öffentlichen Räumen. Texte und Textsorten zwischen Tradition und Innovation. Stuttgart: ibidem-Verlag. (Perspektiven germanistischer Linguistik 14), pp. 109-131. DOI: 10.1515/zfal-2019-2011

KOVACS, L. 2009. Medizin - Macht - Metaphern. Sprachbilder in der Humangenetik und ethische Konsequenzen ihrer Verwendung. Frankurt a. In: Peter Lang. ISBN: 978-3-631-58283-1

LAKOFF, G. - JOHNSON, M. 1980. Metaphors we live by. Chicago: University of Chicago Press. ISBN: 9780226468013 
LIEBERT, W.-A. 2008. Metaphernforschung. In: U. Fix, G. Ungeheuer, H. E. Wiegand (eds.), Handbücher zur Sprach- und Kommunikationswisenschaft. Rhetorik und Stilistik. Berlin: de Gruyter, pp. 743-757. ISBN: 3110137100

LIEBERT, W.-A. 2001. The sociohistorical dynamics of language and cognition. The Emergence of the Metaphor Model 'Money Is Water' in the Nineteenth Century. In: A. Fill, P. Mühlhäuser (eds.), The ecolinguistics reader: Language, ecology and environment. London: Continuum International Publishing Group Ltd., pp. 101-106. ISBN: 9780826481733

LIEBERT, W.-A. 1996. Die transdiskursive Vorstellungswelt zum Aids-Virus. Heterogenität und Einheiten von Textsorten im Übergang von Fachlichkeit und Nichtfachlichkeit. In: H. Kalverkämper (ed.), Fachliche Textsorten. Komponenten Relationen - Strategien. Tübingen: Gunter Narr, pp. 789-811. ISBN: 3-8233-4535-4

MUSOLFF, A. 2006. Metaphor scenarios in public discourse. In: Metaphor and Symbol, vol. 21, pp. 23-38. DOI: https://doi.org/10.1207/s15327868ms2101_2

NIEHR, Th. 2020. Migrationsdiskurs. In: Th. Niehr, J. Killian, J. Schiewe (eds.), Handbuch Sprachkritik. Stuttgart: J. B. Metzler, pp. 225-232. ISBN 978-3-476-

04852-3

PIELENZ, M. 1993. Argumentation und Metapher. Tübingen: Gunter Narr Verlag. ISBN: 978-3-8233-5046-0

POLAJNAR, J. - GREDEL, E. 2018. Diskursive Dynamiken zur Bologna-Reform: Eine kontrastive Analyse metaphorischer Muster im Deutschen und im Slowenischen. In: E. Gredel et al. (Eds.), Diskurs - kontrastiv: Diskurslinguistik als Methode zur Erfassung transnationaler und sprachübergreifender Diskursrealitäten. Bremen: Hempen, pp. 122-149 (Sprache - Politik - Gesellschaft 23).

RICHARDS, I. A. 1986 [1936]. The Philosophy of Rhetoric. New York: Oxford University Press. ISBN: 9780195007152

SALAHSHOUR, N. 2016. Liquid metaphors as positive evaluations: A corpusassisted discourse analysis of the representation of migrants in a daily New Zealand newspaper. In: Discourse, Context \& Media, vol. 13, pp. 73-81. https://doi.org/10.1016/j.dcm.2016.07.002

SEMINO, E. 2002. A sturdy baby or a derailing train? Metaphorical representations of the euro in British and Italian newspapers. In: Text, vol. 22, n. 1, pp. 107-139.

SPIEß, C. 2017a. Metaphern. In: K. S. Roth, M. Wengeler, A. Ziem (eds.), Handbuch Sprache in Politik und Gesellschaft. Berlin/Boston: de Gruyter, pp. 94-115.

SPIEß, C. 2017b. Vom Flüchtlingsstrom bis hin zum Flüchtlingstsunami? Metaphern als Meinungsbildner. In: Erwachsenenbildung.at: Das Fachmedium für Forschung, Praxis und Diskurs, vol. 31, pp. 1-5. URN:nbn:de:0111-pedocs-146148 - http://nbnresolving.org/urn:nbn:de:0111-pedocs-146148.

SPIEß, C. 2014. Diskurslinguistische Metaphernanalyse. In: M. Junge (ed.): Methoden der Metaphernforschung und -analyse. Wiesbaden: VS Springer, pp. 31-58. ISBN 978-3-658-02094-1

SPIEß, C.- KOPCKE, K-M. 2015 (eds.). Metapher und Metonymie. Theoretische, methodische und empirische Zugänge. Berlin/München/Boston: de Gruyter. 2015.

ISBN-10 : 3110374986

SPITZMÜLLER, J. - WARNKE, I. 2011. Diskurslinguistik. Eine Einführung in Theorien und Methoden der transtextuellen Sprachanalyse. Berlin: Walter de Gruyter. ISBN: 978-3-11-021244-0

STEEN, G. J. et al. 2010. A Method for Linguistic Metaphor Identification. Amsterdam: John Benjamins Publishing Company.

STEFANOWITSCH, A. 2006. Words and their metaphor: A corpus-based approach. In: A. Stefanowitsch, S. Th. Gries (eds.): Corpus-based approaches to metaphor and metonymy. Trends in Linguistics. Berlin/New York: Mouton de Gruyter, pp. 1-16. ISBN: 9783110198270

XLinguae, Volume 14 Issue 2, April 2021, ISSN 1337-8384, eISSN 2453-711X 
STORRER, A. 2008. Hypertextlinguistik. In: N. Janich (ed.): Textlinguistik. 15 Einführungen. Tübingen: Narr, pp. 211-227. ISBN - 978-3-8233-6432-0; 3-82336432-4

SAINA, V.-F. 2016. Metafore "begunske" krize: kritična analiza diskurza v Večernjem listu. Diplomsko delo. Ljubljana: FDV.

TANG, P. - QUAN, K. - ZHU, J. 2020. Th Construction of China's Images through Multimodal Metaphor: A Case Study of China-related BBC Documentaries. In: Theory and Practice in Language Studies, vol. 10, n. 9, pp. 1044-1053. ISSN 17992591

TURTON, D. 2003. Conceptualising Forced Migration. RSC Working Paper Series. University of Oxford. Available oline: https://www.rsc.ox.ac.uk/files/files-1/wp12conceptualising- forced-migration-2003.pdf (7.1.2021)

VAN DER VALK, I. 2003. Right-wing Parliamentary Discourse on Immigration in France. In: Discourse \& Society vol. 14, n. 3, pp. 309, 48. ISSN: 0957-9265

VAN DIJK, T. A. 1993. Principles of Critical Discourse Analysis. Discourse and Society, vol. 4, n. 2, pp. 249-283. Available online: https://doi.org/10.1177/0957926593004002006

WARNKE, I. H. 2012. Diskursive Grenzen des Wissens - Sprachwissenschaftliche Bemerkungen zum Nichtwissen als Erfahrungslosigkeit und Unkenntnis. In: N. Janich, A. Nordmann \& L. Schebek (Eds.), Nichtwissenskommunikation in den Wissenschaften.Interdisziplinäre Zugänge, pp. 51-69. Frankfurta. M. et al.: Peter Lang. DOI: https://doi.org/10.3726/b14164

ZIEM, A. 2010. Kollokationen, Konkordanzen und Metaphern. Krisenszenarien im SPIEGEL. In: Aptum vol. 6, n. 2, pp. 157-169. ISSN 1614-905X

\section{Corpus}

Wikipedia article (2021a): Europäische Flüchtlingskrise. https://de.wikipedia.org/wiki/Europ\%C3\%A4ische_Fl\%C3\%BCchtlingskrise. Wikipedia talk page (2021a): talk page to article Europäische Flüchtlingskrise. https://de.wikipedia.org/wiki/Diskussion:Europ\%C3\%A4ische_Fl\%C3\%BCchtlingskr ise.

Wikipedia article (2021b): Flüchtlingskrise ind Deutschland 2015/2016 https://de.wikipedia.org/wiki/Fl\%C3\%BCchtlingskrise_in_Deutschland_2015/2016 Wikipedia talk page (2021b): talk page to article Flüchtlingskrise ind Deutschland 2015/2016.

https://de.wikipedia.org/wiki/Diskussion:Fl\%C3\%BCchtlingskrise_in_Deutschland_2 $015 / 2016$

Words: 8582

Characters: 61448 (34,14 standard pages)

Janja Polajnar Lenarčič

Derpartment of German, Swedisch und Dutch

Faculty of Arts, University of Ljubljana

Aškerčeva 2, 1000 Ljubljana

Slovenia

Janja.PolajnarLenarcic@ff.uni-lj.si 